\title{
Role of the sub-antarctic shrimp Nauticaris marionis in coupling benthic and pelagic food-webs
}

\author{
Renzo Perissinotto $^{1,2}$, Christopher McQuaid ${ }^{1}$ \\ ${ }^{1}$ Southern Ocean Group, Department of Zoology, Rhodes University, Grahamstown 6140, South Africa \\ ${ }^{2}$ Department of Oceanography, Dalhousie University, Halifax, Nova Scotia, Canada B3H 4J1
}

\begin{abstract}
The seas around the Prince Edward Islands exhibit enhanced phytoplankton production and large populations of birds and seals. However, phytoplankton blooms are hardly utilised by holozooplankton grazers. Much of the phytoplankton biomass sinks to the seabed, supporting a rich benthos, and the link with higher trophic levels is unclear. A large population of the shrimp Nauticaris marionis is concentrated in the inter-island plateau forming a suprabenthic layer extending 5 to $10 \mathrm{~m}$ above the bottom. Megalope larvae of $N$. marionis exhibit vertical diurnal migration in the watercolumn and rhythms in gut pigment content. The main prey items in adult shrimp guts, however, are benthic suspension feeders and no grazing on phytoplankton occurs. This suggests that, while megalope larvae utilize phytoplankton directly as a food source, adult shrimps do so indirectly, via their grazing on benthic suspension feeders. As $N$. marionis forms a large component of the stomach contents of many visual predators, this indicates a key role for the shrimp in making pelagic production indirectly available to large predators
\end{abstract}

\section{INTRODUCTION}

Like many islands in the Southern Ocean, the Prince Edward Archipelago $\left(47^{\circ} \mathrm{S}, 38^{\circ} \mathrm{E}\right)$ supports enormous seasonal populations of predatory pinnipeds and marine birds, the two combined being estimated in excess of 2 million (Williams et al. 1979, Condy 1981). The seas around the islands are also characterized by an island-mass effect which results in enhanced primary productivity levels and the repeated formation of dense phytoplankton blooms, with chlorophyll a concentrations of 1.5 to $3.0 \mathrm{mg} \mathrm{m}^{-3}$ (Boden 1988, Perissinotto et al. 1990b). Utilization of these blooms by the community of planktonic herbivores is poor (Perissinotto \& Boden 1989) and much of this production seems to be transferred to the rich benthic community by senescence and sedimentation. However, few of the island-based predators feed directly on the benthos (Condy 1981, Brown \& Klages 1987, Espitalier-Noel et al. 1988, Adams \& Klages 1989). This study examines the link between phytoplankton production and the maintenance of large predator populations by inves- tigating the position of the abundant shrimp Nauticaris marionis in these food-webs.

Nauticaris marionis is a sub-Antarctic caridean shrimp with a distribution that ranges from southern New Zealand to the Prince Edward Islands. It is found in abundance at the Auckland and Campbell Islands, on the Campbell Plateau (Yaldwyn 1965) and is present, though not abundant, at both the Crozet and Kerguelen archipelagos (Ledoyer 1979). The Prince Edward Islands represent the western-most limit of its distribution (Boden \& Parker 1986), and further west it is replaced by the congeneric $N$. magellanica which occurs at Gough Island, the Falkland Islands and in sub-Antarctic South America (Yaldwyn 1965).

Since the earliest benthic surveys of the Prince Edward Island seas, the local population of Nauticaris marionis has been noted for its high abundance, compared to populations at other sub-Antarctic islands (Bate 1888, Ledoyer 1979). $N$. marionis is frequently found in the stomach contents of a variety of visual predators and constitutes the dominant component of the diet of the Gentoo penguins and Imperial cormor- 
ants inhabiting the archipelago (Espitalier-Noel et al. 1988, Adams \& Klages 1989).

\section{MATERIAL AND METHODS}

Sampling procedure. The Prince Edward Archipelago lies between Africa and Antarctica and consists of 2 small islands, Marion (area ca $300 \mathrm{~km}^{2}$ ) and Prince Edward (area ca $100 \mathrm{~km}^{2}$ ), $22 \mathrm{~km}$ apart on a shallow plateau of about $200 \mathrm{~m}$ depth. The plateau itself is roughly $1000 \mathrm{~km}^{2}$ in area and drops off sharply into deep waters (3000 m; Fig. 1). The benthic epifauna of the islands was sampled during 4 cruises of the SA 'Agulhas' in November 1983, March 1984, April 1987 and April 1989. A total of 65 stations were dredged by means of a D-net $\left(0.5 \mathrm{~m}^{2}\right.$ aperture $)$ fitted with a depressor plate, towed at about $0.5 \mathrm{~m} \mathrm{~s}^{-1}$, or using a scallop dredge towed at 2 knots. Net hauls in the suprabenthic layer were also made during April 1989, using $500 \mu \mathrm{m}$ mesh Bongo and $4 \mathrm{~mm}$ mesh RMT-2 nets. The fishing depth of the nets was controlled by a Universal Underwater Unit $\left(\mathrm{U}^{3}\right)$ while the target layers were identified with a SIMRAD $120 \mathrm{kHz}$ echo-sounder.
In addition, in situ photographs of the benthic community were taken at 30 stations along 3 transects between Marion and Prince Edward islands, using an underwater camera deployed from the ship.

Dredged samples were sorted into taxa and a determination of the biomass (expressed as $\mathrm{g}$ wet $\mathrm{wt} \mathrm{m}^{-2}$ of substratum) was carried out for the major components of the epibenthic community.

Feeding biology. Gut content analyses were performed on preserved adult Nauticaris marionis sampled in 1984, 1987 and 1989 at stations located on the inter-island plateau. The guts of 30 male and 30 female shrimps were removed and their contents examined under $400 \times$ magnification.

Possible grazing of phytoplankton blooms by Nauticaris marionis was examined by size-selectivity grazing experiments. Naturally occurring phytoplankton was collected with a submersible pump and concentrated on $0.2 \mu \mathrm{m}$ Nuclepore filters to experimental concentrations of about $1.5 \mu \mathrm{g} \mathrm{chl} \mathrm{a} \mathrm{l}^{-1}$. Three experimental 2 l bottles, each containing 3 shrimps, and 2 control bottles with no shrimps, were filled with the phytoplankton mixture and rotated on a plankton wheel (ca $1 \mathrm{rpm}$ ) in the dark, in a cold room (ca 9 to

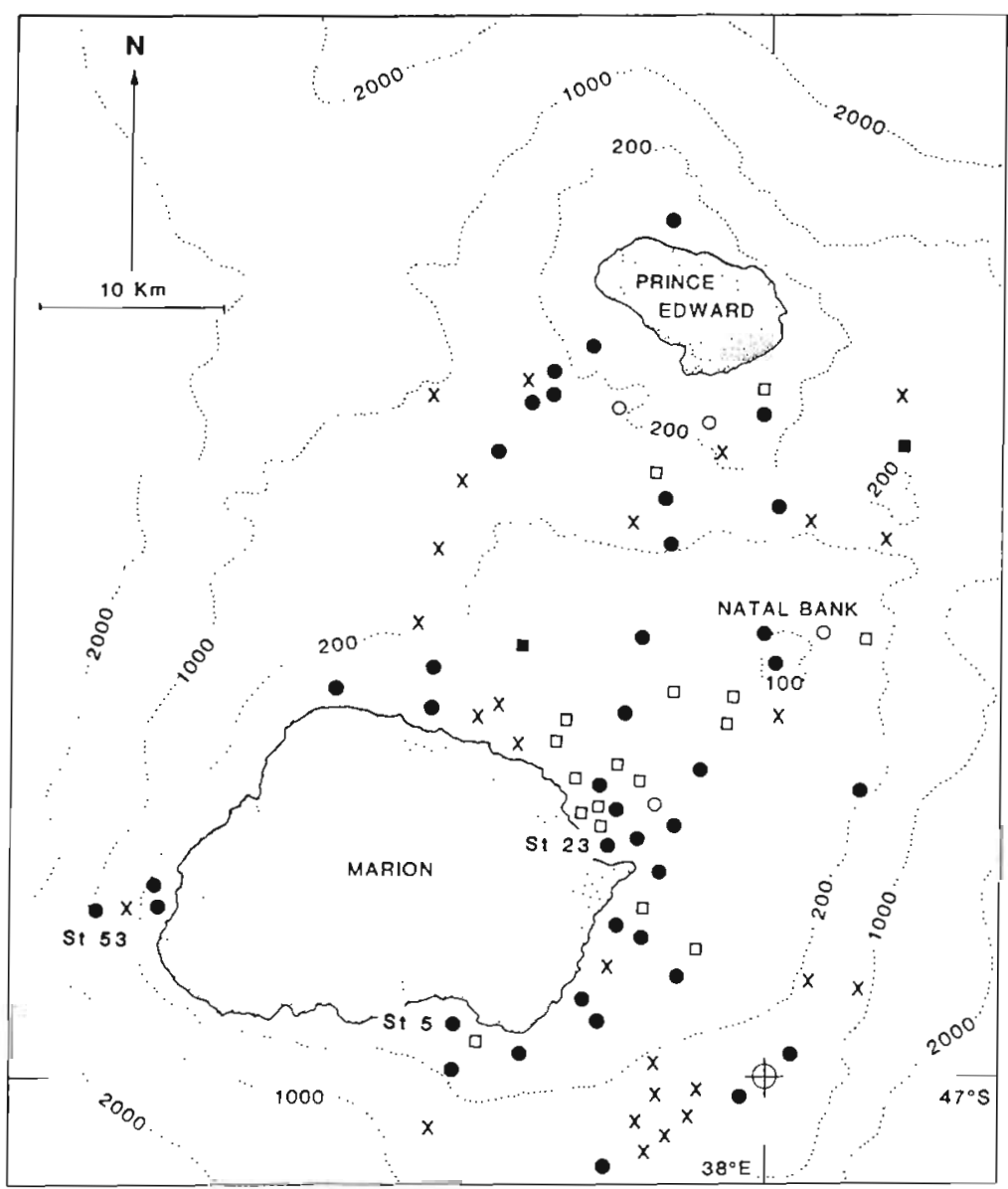

- HMS Challenger, 1873 (Bate 1888)

口 Marion Dufresne, 1976 (Ladoyer 1979)

- SA Aguinas, 1983-1984 (Parker 1984)

- SA Agulhas, 1987-1889 (Gianakouras unpubl.)

Fig. 1. Nauticaris marionis. Occurrence at the Prince Edward Archipelago based on 4 benthic surveys. $X$ : dredge stations where no shrimps were found 
$10^{\circ} \mathrm{C}$ ) for $24 \mathrm{~h}$. Duplicate water samples (100 ml) were taken from each bottle at the beginning and end of the incubation for chlorophyll $a$ and phaeopigment analysis. Five size fractions of phytoplankton $(200-37,37-20$, $20-5,5-1$, and $1-0.2 \mu \mathrm{m}$ ) were obtained by multiple serial filtration on a Sartorius Membranfilter column. Pigments from the different filters were extracted overnight at $4{ }^{\circ} \mathrm{C}$ in $10 \mathrm{ml} 90 \%$ acetone and concentrations were calculated from the fluorescence readings on a Turner Model 111 fluorometer (Strickland \& Parsons 1968).

Diurnal variations in gut pigment contents of Nauticaris marionis were measured for freshly caught megalope larvae at $3 \mathrm{~h}$ intervals for $24 \mathrm{~h}$. At each interval, 3 replicates of 3 individuals were placed in a plastic centrifuge tube with $90 \%$ acetone, homogenised with a glass rod, and stored at $-20{ }^{\circ} \mathrm{C}$ for $12 \mathrm{~h}$. The tubes were then spun in a centrifuge for $10 \mathrm{~min}$ at $4000 \times g$ and the pigment content of the acetone extract was measured with a Turner 111 fluorometer, before and after acidification (Mackas \& Bohrer 1976, Dagg \& Walser 1987).

\section{RESULTS}

\section{Benthic community}

Biomass data for November 1983 and March 1984 show that Nauticaris marionis is a major component of the benthic community, being second in importance in terms of biomass only to bryozoan suspension feeders (Fig. 2).

Net tows and dredge samples showed that Nauticaris marionis is widely distributed around the Prince

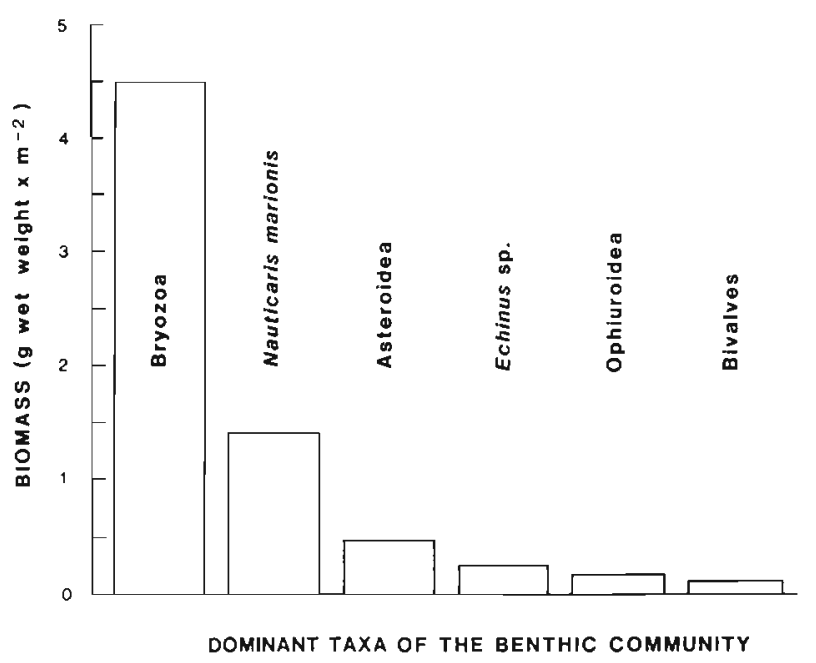

Fig. 2. Biomass of dominant taxa of the benthic community of the Prince Edward Archipelago estimated from dredge samples collected during November 1983 and April 1984
Edward Islands and occurs mainly within the $200 \mathrm{~m}$ depth contours (Fig. 1). The shallowest depth at which it was recorded was 30 to $33 \mathrm{~m}$ (Stn 23 on the east coast of Marion Island) while the deepest was between 606 and $775 \mathrm{~m}$ ( $\operatorname{Stn} 53$ on the west coast of Marion Island). On the inter-island plateau the shrimp forms a suprabenthic layer which extends 5 to $10 \mathrm{~m}$ above the bottom and can be detected as a distinct scatterer with a 120 $\mathrm{kHz}$ echo-sounder (Fig. 3).

Abundance estimates from dredge samples are as high as 25 ind. $\mathrm{m}^{-2}$, but photographs of the bottom show much higher densities, with a maximum of about 80 ind $\mathrm{m}^{-2}$ at $61 \mathrm{~m}$ depth, on the southeast coast of Marion Island (Stn 5). However, as photos were taken from ca $2.2 \mathrm{~m}$ above the bottom (i.e. beneath the scattering layer), it is possible that even this value represents a significant underestimate of the true population density.

The dredge samples collected in autumn (March/ April) usually consisted of a mixture of adult shrimps and megalope larvae. A typical carapace size distribution of the population of Nauticaris marionis during this period is given in Fig. 4. No larval stages were recorded in early summer (November). While adult shrimps were very sparsely represented in net tows away from the benthic layer, the megalope larvae were regularly found in midwater RMT-2 hauls. This occurred mostly during night-time, when megalope concentrations of up to 3 ind. $\mathrm{m}^{-3}$ were recorded in the upper layer.

\section{Feeding biology}

The main prey items in the gut contents of Nauticaris marionis were benthic suspension feeders such as bryozoans, foraminiferans, corals and harpacticoid copepods (Table 1). There was a significant difference in frequency and abundance of some items between male and female stomach contents. In particular, males ingested more foraminiferans and bryozoans and fewer copepods than females. Also, large prey species such as euphausiids and amphipods were found only in female stomachs. Gut contents of both sexes (adults) included a relatively small amount of unidentifiable amorphous material, but no recognizable plant fragments, either phytoplankton or macrophyte, could be found in this material.

Grazing experiments on phytoplankton suspensions showed that none of the size fractions of the naturally occurring algal community were ingested by adult Nauticaris marionis ( $\mathrm{t}$-test, $\mathrm{p}>0.05$ ). However, phytoplankton pigments (chlorophyll $a$ and phaeopigments) were detected in the gut content of megalope larvae. Larvae also exhibited strong diurnal feeding rhythms with night-time gut pigment peaks reaching maximum 
(U) $H \perp d \exists O$

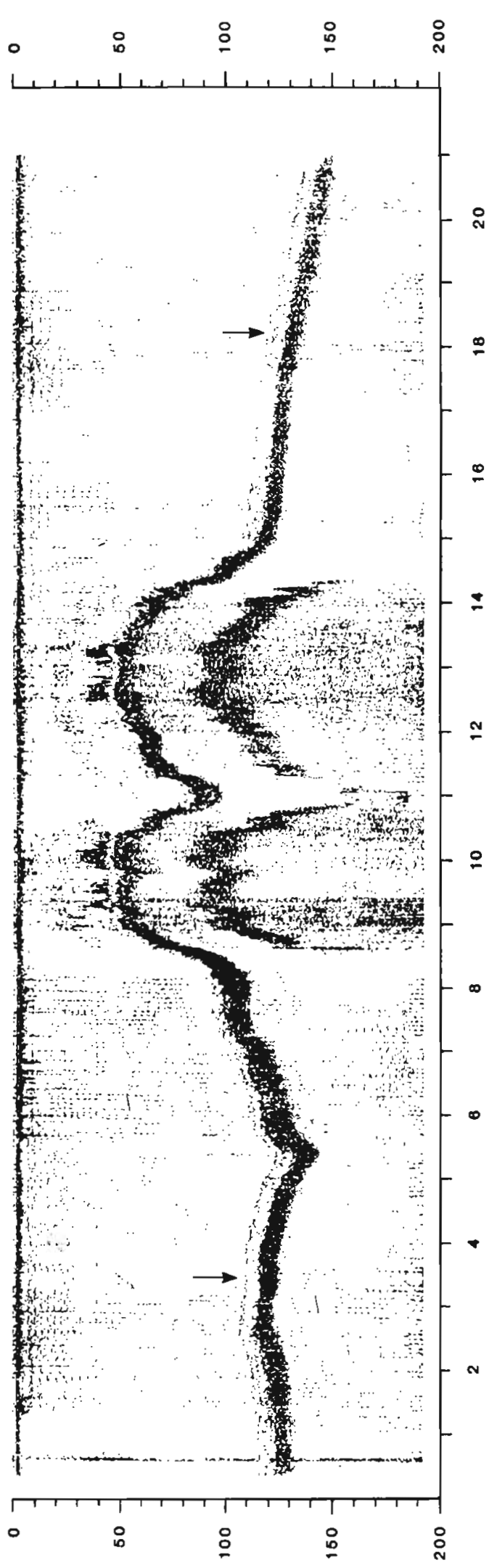

(w) $H \perp d \exists O$

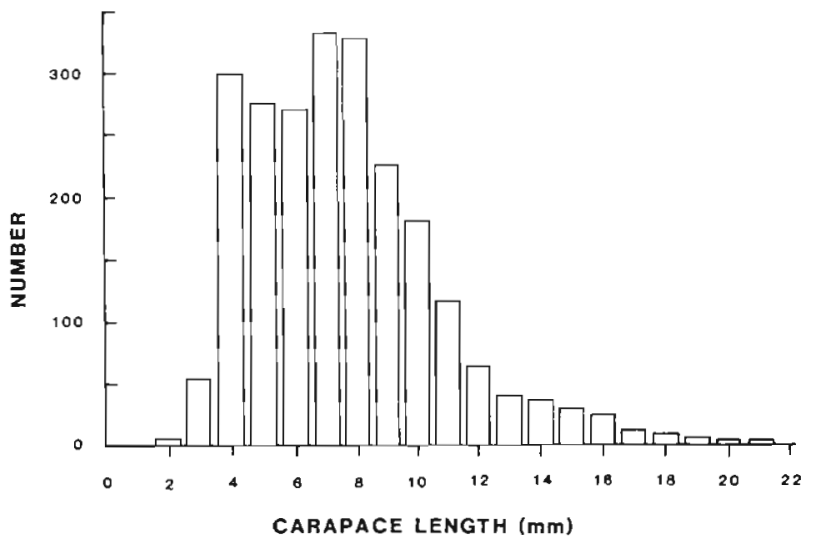

Fig. 4. Nauticaris marionis. Size distribution (as carapace length) from bottom samples collected in April 1984. Sample size, $N=2295$. (After Parker 1984.) Carapace length range of adults: 7 to $21 \mathrm{~mm}$; megalope larvae: 2 to $7 \mathrm{~mm}$

Table 1. Nauticaris marionis. Occurrence of prey items in stomach contents. Frequency $(F)$ : no. of stomachs in which the prey was found. Abundance (A): total no. of prey found in the stomachs. t-test results represent differences in prey abundance between male and female gut contents. Significance levels (Sig.): $\cdot 99 \% ; \cdot 95 \%$; ns: not significant

\begin{tabular}{|c|c|c|c|c|c|}
\hline \multirow[t]{2}{*}{ Prey item } & \multicolumn{2}{|c|}{$\begin{array}{c}\text { Male } \\
(\mathrm{n}=30)\end{array}$} & \multicolumn{2}{|c|}{$\begin{array}{l}\text { Female } \\
(\mathrm{n}=30)\end{array}$} & \multirow[t]{2}{*}{ Sig. } \\
\hline & $\mathrm{F}$ & A & $\mathrm{F}$ & A & \\
\hline Foraminifera & 27 & 256 & 24 & 125 & $\cdots$ \\
\hline Madreporaria (fragments) & 2 & 3 & 2 & 13 & ns \\
\hline Octocorallia (fragments) & 7 & 15 & 5 & 31 & ns \\
\hline Gastropod veligers & 2 & 2 & 1 & 1 & ns \\
\hline Bivalve veligers & 2 & 6 & 3 & 13 & ns \\
\hline Limacina sp. & 7 & 7 & 2 & 2 & ns \\
\hline Ostracods & 1 & 2 & 2 & 5 & ns \\
\hline Calanoid copepods & 8 & 18 & 16 & 36 & ns \\
\hline Harpacticoid copepods & 7 & 11 & 16 & 30 & $\cdots$ \\
\hline Cyclopoid copepods & 2 & 3 & 3 & 5 & ns \\
\hline Amphipods & 1 & 1 & 7 & 7 & $\cdot$ \\
\hline Euphausiids & 0 & 0 & 6 & 6 & $\cdots$ \\
\hline Bryozod (fragments) & 30 & 318 & 21 & 194 & $\cdots$ \\
\hline Echinoids (fragments) & 1 & 2 & 3 & 3 & ns \\
\hline Crinoids (fragments) & 0 & 0 & 1 & 1 & $\mathrm{~ns}$ \\
\hline Tunicates (fragments) & 1 & 3 & 0 & 0 & ns \\
\hline Chaetognaths & 0 & 0 & 2 & 2 & ns \\
\hline
\end{tabular}

values of about $50 \mathrm{ng}$ pigm. ind ${ }^{-1}$ between $23: 00$ and 02:00 h (Fig. 5).

\section{DISCUSSION}

The marine ecosystem of the Prince Edward Archipelago experiences repeated, seasonal occurrences of phytoplankton blooms concentrated in the inter-island region (Allanson et al, 1985, Boden 1988, 


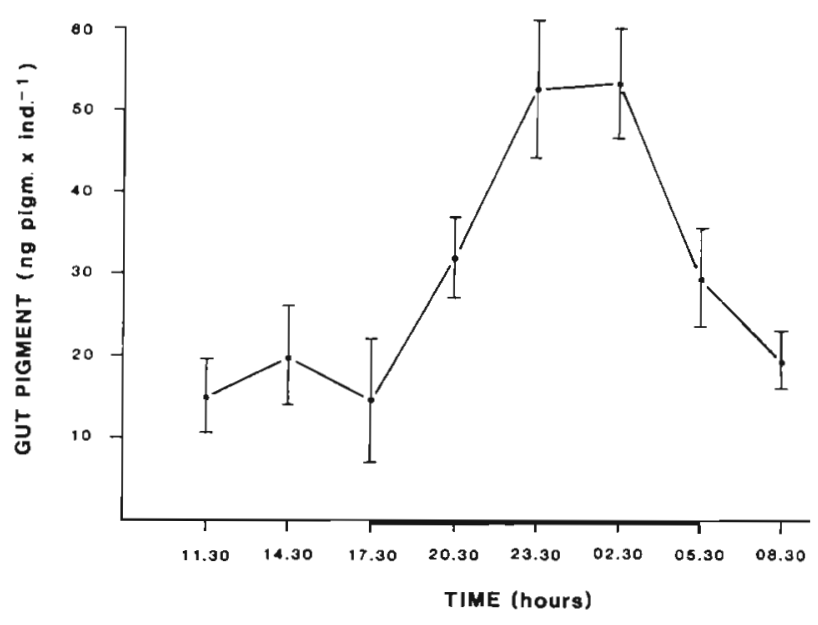

Fig. 5. Nauticaris marionis. Diumal variations in total gut pigment levels of megalope larvae at the Prince Edward Archipelago during April/May 1989. Vertical bars represent standard deviation about the mean. Period of darkness is indicated by thickening of the horizontal axis

Perissinotto et al. 1990b). The bulk of the biomass of these blooms is composed of net-size phytoplankton (200 to $20 \mu \mathrm{m})$, while the contribution of the nano- (20 to $1 \mu \mathrm{m}$ ) and picoplankton (1 to $0.2 \mu \mathrm{m}$ ) to the local community is quite low, compared to other areas of the Southern Ocean, and amounts to only $21.5 \pm 6.33 \%$ of the total (El Sayed et al. 1979). The diatoms Rhizosolenia curvata and Chaetoceros radicans and the silicoflagellate Dictyocha speculum dominate the bloom communities of the Prince Edward Archipelago (Allanson et al. 1985, Boden 1988). None of these species is known to be a staple in zooplankton diets (Schnack 1979, Perissinotto \& Boden 1989). Indeed, size-selectivity experiments on zooplankton feeding on naturally occurring phytoplankton show that the zooplankton community of the Prince Edward Island seas has very little grazing impact on the net-size phytoplankton (Perissinotto \& Boden 1989, Perissinotto et al. 1990a). This implies that the rich food source stored in the phytoplankton blooms is scarcely exploited by the pelagic herbivores.

Although some degree of horizontal dispersion of the blooms does probably occur, it seems likely that most of this biomass sinks below the mixed layer in the form of senescent phytoplankton cells and/or resting spores. Recent measurements of the sedimentation rate of particulate matter in the area, by means of moored traps, indicate that relatively high values can occur, especially in the shallowest part of the inter-island region (up to $40 \mathrm{~g}$ of suspended solid $\mathrm{m}^{-2} \mathrm{~d}^{-1}$; Bailey unpubl.). Also, resting spores, particularly of Chaetoceros radicans in the bloom stage, have often been found in the phytoplankton of the Prince Edward Islands and appear to corroborate a direct link between pelagic primary producers and benthic suspensoid feeders (Fryxell et al. 1981, Perissinotto \& Boden 1989).

The megalope larvae of Nauticaris marionis exhibit both vertical diurnal migration in the water column and rhythms in gut pigment content (Fig. 5) which clearly indicate nocturnal feeding and the ability to utilise phytoplankton as a food source. Adult shrimps, however, do not graze on phytoplankton and the large resident population is maintained only indirectly by pelagic production. Gut contents of $N$. marionis reveal the overriding importance of benthic suspension feeders (Table 1) which are themselves maintained at high densities by imports from the upper mixed layer of the water column.

Differences between gut contents of male and female shrimps are likely to be artifactual as mean size for females $(32.3 \pm 4.5 \mathrm{~mm}$ ) was significantly higher than for males $(25.6 \pm 3.3 \mathrm{~mm})$. Combined abundance data for both sexes indicate that over $90 \%$ of gut contents was formed by bryozoans (54\%) and benthic foraminiferans $(40 \%)$, the former being a particularly important component of the benthic community (Fig. 2; Parker 1984, Gianakouras unpubl.).

A number of recent investigations on the ecology of the seabird community of the Prince Edward Archipelago have revealed the importance of Nauticaris marionis as a prey item (Table 2). To our knowledge, in no other Southern Ocean ecosystem has $N$. marionis been found to be an important component of the diet of seabirds (see review by Croxall 1987). At the Prince Edward Islands, $N$. marionis is the dominant prey item in the diets of Gentoo penguin and Imperial cormorant, contributing respectively 26 and $19 \%$ by mass to their total annual food consumption (Espitalier-Noel et al. 1988. Adams \& Klages 1989). In 1983/84 the shrimp was the most abundant crustacean in the diets of both Macaroni and Rockhopper penguins, constituting 40 and $60 \%$, respectively, of all crustacean items identified in their stomachs (Brown \& Klages 1987). The shrimp has also been recorded in the stomach contents of the inshore fish Paranotothenia magellanica (Blankley 1982) and the starfish Anasterias rupicola (Blankley \& Grindley 1985; Table 2). Thus, the local stock of $N$. marionis helps to support both land-based and marine predators.

Enhancement of pelagic primary production by the island-mass effect helps the archipelago to sustain high densities of pelagic predators, but only indirectly, through coupling with the benthic food-web. Phytoplankton production appears to be transferred to the benthic community by sedimentation and on to higher trophic levels via the effects of benthic grazing by Nauticaris marionis. This indicates a key role for the shrimp in making pelagic production available to large visual predators. 
Table 2. Nauticaris marionis in the diet of different predator groups at the Prince Edward islands. na: not available; tr: trace only. $\mathrm{N}$ : sample size of predator stomachs examined

\begin{tabular}{|c|c|c|c|c|c|c|}
\hline Predator & $\%$ No. & $\%$ Mass & $\%$ Occurr. & $N$ & Period & Source \\
\hline \multicolumn{7}{|l|}{ Birds } \\
\hline Gentoo penguin & 12 & 26 & 33 & 144 & Mar 84/Mar 85 & Adams \& Klages (1989) \\
\hline King penguin & $\operatorname{tr}$ & $\operatorname{tr}$ & 4 & 120 & Mar 84/Mar 85 & Adams \& Klages (1987) \\
\hline Macaroni penguin & 5 & na & 26 & 30 & Dec $83 /$ Feb 84 & Brown \& Klages (1987) \\
\hline Rockhopper penguin & 9 & na & 24 & 34 & $\mathrm{Jan} / \mathrm{Mar} 84$ & Brown \& Klages (1987) \\
\hline Imperial cormorant & 87 & 19 & 47 & 47 & Apr $84 /$ Mar 85 & Espitalier-Noel et al. (1988) \\
\hline \multicolumn{7}{|l|}{ Fish } \\
\hline Paranotothenia magellanica & 2 & 4 & 5 & 129 & May 79/May 80 & Blankley (1982) \\
\hline \multicolumn{7}{|l|}{ Starfish } \\
\hline Anasterias rupicola & $\operatorname{tr}$ & $\operatorname{tr}$ & na & 322 & Sep 79/May 80 & Blankley \& Grindley (1985) \\
\hline
\end{tabular}

Acknowledgements. We are particularly indebted to D. Gianakouras for kindly providing the dredge data and photographs of the 1987 to 1989 benthuc survey. A. A. Robertson of the Sea Fisheries Research Institute, Cape Town, arranged most of the equipment and technical assistance for the investigation. The co-operation of the masters, officers and crew of the SA 'Agulhas' is also greatly appreciated. This work forms part of a project funded by the Department of Environment Affairs and co-ordinated by the South African Scientific Committee for Antarctic Research (SASCAR).

\section{LITERATURE CITED}

Adams, N. J., Klages, N. T (1987). Seasonal variation in diet of the King penguin (Aptenodytes patagonicus) at subAntarctic Marion Island. J. Zool., Lond. 212: 313-334

Adams, N. J., Klages, N. T. (1989). Seasonal variation in the diet of the Gentoo penguins (Pygoscelis papua) at subAntarctic Marion Island. Col. Waterbirds 12: 30-36

Allanson, B. R., Boden, B. P., Parker, L. D., Duncome Rae, C. M. (1985). A contribution to the oceanology of the Prince Edward Islands. In: Siegfried, W R., Condy, P. R., Laws, R. M. (eds.) Antarctic nutrient cycles and food webs. Springer, Berlin, p. 38-45

Bate, C. S. (1888). Report on the Crustacea Macrura collected by HMS Challenger during the years 1873-76. Challenger Rep., Zool. XXIV. 1-942

Blankley, W. O. (1982). Feeding ecology of three inshore fish species at Marion Island (Southern Ocean). S. Afr. J. Zool. 17: $164-170$

Blankley, W. O., Grindley, J. R. (1985). The intertidal and shallow subtidal food web at Marion Island. In: Siegfried W. R., Condy, P. R., Laws, R. M. (eds.) Antarctic nutrient cycles and food webs. Springer, Berlin, p. 630-636

Boden, B. P. (1988). Observations of the island mass effect in the Prince Edward Archipelago. Polar Biol. 9:61-68

Boden, B. P., Parker, L. D. (1986). The plankton of the Prince Edward Islands. Polar. Biol. 5: 81-93

Brown, C. R., Klages, N. T. (1987). Seasonal and annual variation in diets of Macaroni (Eudyptes chrysolophus chrysolophus) and Southern Rockhopper ( $E$. chrysocome chrysocome) penguins at sub-Antarctic Marion Island. J. Zool., Lond. 212: 7-28

Condy, P. R. (1981). Annual food consumption, and seasonal fluctuations in biomass of seals at Marion Island. Mammalia 45: $21-30$
Croxall, J. P. (1987). Seabirds: feeding ecology and role in marine ecosystems. Cambridge University Press, Cambridge

Dagg, M. J., Walser, W. D. (1987). Ingestion, gut passage and egestion by the copepod Neocalanus plumchrus in the laboratory and in the subarctic Pacific Ocean. Limnol. Oceanogr. 32: 178-188

El Sayed, S. Z., Benon, P., David, P., Grindley, J. R., Murail, J.-F. (1979). Some aspects of the biology of the watercolumn studied during the Marion Dufresne cruise 08. Com. natn. fr. Rech. antarct. 44:127-134

Espitalier-Noel, G., Adams, N. J., Klages, N. T. (1988). Diet of the Imperial cormorant Phalacrocorax atriceps at subAntarctic Marion Island. Emu 88: 43-46

Fryxell, G. A., Villareal, T. A., Doucette, G. J. (1981). Diatom resting spores and Agulhas collections. Antarct. J. U. S. 16 $128-130$

Ledoyer, M. (1979). Caridea (Crustacea, Decapoda) des lles Kerguelen, Crozet, Marion et Prince Edward, et du sud de Madagascar (Banc Walters), des campagnes MD.03, MD.04, et MD.08 du M/S 'Marion Dufresne'. Con. natn. fr. Rech. antarct. 44: 137-153

Mackas, D., Bohrer, R. (1976). Fluorescence analysis of zooplankton gut contents and an investigation of diel feeding patterns. J. exp. Mar. Biol. Ecol. 25: 77-85

Parker, L. D. (1984). A contribution to the oceanology of the Prince Edward Islands. M.Sc. thesis, Rhodes University, Grahamstown

Perissinotto, R., Boden, B. P. (1989). Zooplankton-phytoplankton relationships at the Prince Edward Islands during April/May 1985 and 1986. S. Afr. J. Antarct. Res. 19: 26-30

Perissinotto, R., Allanson, B. R., Boden, B. P. (1990a). Trophic relations within the island seas of the Prince Edward Archipelago (Southern Ocean\}. In: Barnes, M., Gibson, R. $N$. (eds.) Trophic relationships in the marine environment. Proc. 24th Eur. Mar Biol. Symp. Aberdeen University Press, Aberdeen, p. 296-314

Perissinotto, R., Duncombe Rae, C. M., Allanson, B. R., Boden, B. P. (1990b). Vertical stability as a controlling factor of the marine phytoplankton production at the Prince Edward Archipelago (Southem Ocean). Mar. Ecol. Prog. Ser. 60: 205-209

Schnack, S. B. (1979). Feeding of Calanus helgolandicus on phytoplankton mixtures. Mar. Ecol. Prog. Ser. 1: 41-47

Strickland, J. D. H., Parsons, T R. (1968). A practical handbook of seawater analysis. Bull. Fish. Res. Bd Can. 167 $1-311$ 
Williams, A. J., Siegfried, W. R., Burger, A. I., Berruti, A. (1979). The Prince Edward Islands: a sanctuary for seabirds in the Southern Ocean. Biol. Conserv. 15: $59-71$

This article was submitted to the editor
Yaldwyn, J. C. (1965). Antarctic and Subantarctic decapod Crustacea. In: Van Oye, P., Van Mieghem, J. (eds.) Biogeography and ecology in Antarctica. Monographiae Biologicae 15. Junk, The Hague, p. 324-332

Manuscript first received: November 15, 1989 Revised version accepted: March 27, 1990 